\title{
Historical insights on nearly 130 years of research on Paleozoic radiolarians
}

\author{
Taniel DANELIAN \\ Univ. Lille, CNRS, UMR 8198 - Évo-Éco-Paléo, \\ F-59000 Lille (France) \\ taniel.danelian@univ-lille1.fr \\ Jonathan C. AITCHISON \\ School of Earth and Environmental Sciences, \\ University of Queensland, St Lucia, Qld 4072 (Australia) \\ jona@uq.edu.au \\ Paula NOBLE \\ Department of Geological Sciences and Engineering, University of Nevada, \\ Reno, Nevada 89557-0138 (United States) \\ and Univ. Lille, CNRS, UMR 8198 - Évo-Éco-Paléo, \\ F-59000 Lille (France) \\ noblepj@unr.edu \\ Martial CARIDROIT \\ Univ. Lille, CNRS, UMR 8198 - Évo-Éco-Paléo, \\ F-59000 Lille (France) \\ martial.caridroit@univ-lille1.fr \\ Noritoshi SUZUKI \\ Department of Earth Science, Graduate School of Science, \\ Tohoku University, 6-3 Aoba, Aramaki, Aoba-ku, Sendai 980-8578 (Japan) \\ norinori@m.tohoku.ac.jp \\ Luis O'DOGHERTY \\ Facultad de Ciencias del Mar, Universidad de Cadiz, \\ E-11510 Puerto Real (Spain) \\ luis.odogherty@uca.es
}

Published on 29 September 2017

urn:Isid:zoobank.org:pub:9905A429-A12A-4132-9091-3B2F8B24CC68

Danelian T., Aitchison J. C., Noble P., Caridroit M., Suzuki N. \& O’Dogherty L. 2017. - Historical insights on nearly 130 years of research on Paleozoic radiolarians, in Danelian T., Caridroit M., Noble P. \& Aitchison J. C. (eds), Catalogue of Paleozoic radiolarian genera. Geodiversitas 39 (3): 351-361. https://doi.org/10.5252/g2017n3a2

\section{ABSTRACT}

This paper summarizes and highlights the history of descriptive genus-level taxonomy on Paleozoic radiolarians grouped in five major phases: 1) initial discoveries in the 1890s; 2) ignored during the first half of the 1900s; 3) renewed interest during the 1950s to 1970s; 4) the "fast" years of the late 1970s to 1990s; and 5) the early $21^{\text {st }}$ century quest for the oldest and significant progress in the late Permian. In the 1890s, radiolarians were identified with certainty by Hinde in Ordovician radiolar- 
KEY WORDS

History of science,

Paleozoic,

radiolarians,

taxonomic analysis.

ian cherts. Following Hinde's great discovery, and after a 50-year dormant period, Deflandre revived the study of Paleozoic radiolarians through his groundbreaking study of Albaillella from Carboniferous phosphatic nodules, combined with his genius for understanding evolutionary implications. Additional important work was conducted in this third phase by Foreman, particularly with respect to the description of the radiolarian internal structures based on material extracted from Devonian carbonate nodules. The late 1970s saw an expansion in studies that made extensive use of the SEM for the description of Paleozoic radiolarians, many of which had been extracted from chert using HF methods. The potential of radiolarians to unveil the structure and geodynamic evolution of Paleozoic orogenic belts stimulated taxonomic interest during the 1980s and 1990s, a prerequisite for the elaboration of radiolarian biostratigraphic schemes, which was successfully achieved for the upper Paleozoic. The fifth phase follows the discovery of well-preserved Middle Cambrian radiolarians from Australia at the end of the $20^{\text {th }}$ century and subsequent description by Won of beautifully preserved Cambrian and Ordovician fauna from western Newfoundland. Research on early Paleozoic radiolarians was the main driver for the increase of the number of new genera for the last two decades.

\section{RÉSUMÉ}

Regard historique sur presque 130 ans de recherches sur les radiolaires paléozö̈ques.

Ce travail synthétise l'histoire des études taxonomiques des radiolaires paléozoïques que l'on peut répartir en cinq phases majeures: 1) découvertes initiales durant les années $1890 ; 2$ ) ignorés durant la première moitié du 20ème siècle; 3) renouveau d'intérêt pendant les années 1950 à 1970;4) les années glorieuses de la période 1970 à 1990 ; et 5) le début du 21 ème siècle avec ses travaux sur les formes les plus anciennes, accompagnés de progrès importants pour le Permien supérieur. Pendant les années 1890, les premiers radiolaires ont été déterminés avec certitude par Hinde; ils provenaient de radiolarites ordoviciennes. Suite à la grande découverte de Hinde, et après une période dormante de plus de 50 ans, Deflandre a réveillé l'intérêt de l'étude des radiolaires paléozoïques par son étude révolutionnaire du genre Albaillella, issu de nodules phosphatés du Carbonifère; son talent lui a aussi permis d'en déduire les implications évolutives. Un travail, également important, a été mené lors de cette troisième phase par Foreman, plus particulièrement avec la description des structures internes des radiolaires sur la base d'assemblages extraits de nodules carbonatés du Dévonien. La fin des années 1970 a enregistré un accroissement du nombre d'études grâce à l'utilisation généralisée du microscope électronique à balayage $(\mathrm{MEB})$ pour décrire des radiolaires paléozoïques dont un grand nombre a été extrait de jaspes en utilisant l'acide fluorhydrique. Le potentiel des radiolaires pour dévoiler la structure et l'évolution géodynamique des ceintures orogéniques a stimulé l'intérêt pour la taxonomie durant les années 1980 et 1990, condition indispensable pour l'élaboration des échelles biostratigraphiques basées sur les radiolaires; cela fut fait avec succès pour le Paléozoïque supérieur. La cinquième phase a commencé après la découverte de radiolaires bien préservés du Cambrien moyen d'Australie à la

MOTS CLÉS

Histoire des sciences,

Paléozoïque, radiolaires, analyse taxonomique. fin du 20e siècle et la description par Won, ultérieurement, de magnifiques faunes à radiolaires d'âge Cambrien supérieur à Ordovicien inférieur provenant de l'ouest de Terre Neuve. Les recherches sur les radiolaires du Paléozoïque inférieur furent donc le moteur principal de la description de nouveaux genres durant ces deux dernières décennies.

\section{INTRODUCTION}

Many studies have provided insights to the historical development of research on radiolarians (e.g. De Wever 1982; Ichikawa 1982; Zhamoida 1981; Nagai 1995; Wang 2001; De Wever et al. 2001; O'Dogherty et al. 2009) and they have recognized several distinct periods discussed below. The remarkable early taxonomic work of Haeckel (1887) provided a simple taxonomic framework. However, this study was largely based on external characteristics and geometry rather than biological concepts. The artificial character of this classification had the unintended consequence of misleading the scientific community into concluding that there was a high level of evolutionary conservatism in this important plankton group. The development of the Deep Sea Drill- ing Project (DSDP) during the 1960s and 1970s provided adequately complete material to establish that there was a great degree of evolutionary change that could be observed in the radiolarian fossil record. Most importantly, from the very onset of DSDP (Riedel 1967a; Riedel \& Hays 1969; Riedel \& Sanfilippo 1974) radiolarians provided critical evidence in support of the sea-floor spreading hypothesis that played a crucial role in establishment of the theory of plate tectonics. The impetus provided by DSDP drove new radiolarian studies and the taxonomic focus shifted progressively towards closer examination of most internal elements and structures of the test, finally breaking free of the constraints imposed by Haeckel's scheme. During the 1970s, the extensive use of the Scanning Electron Microscope (SEM) and the development of the hydrofluoric acid 
method for the extraction of radiolarians from cherts provided an abundance of matrix free material and the means to study their fine structure. The establishment of increasingly elaborate biostratigraphic schemes stimulated the interest of the scientific community for taxonomic studies. At the same time realization that radiolarians could be extracted from deep sea cherts, and that they held the key to unlocking the stratigraphy of subduction complexes, associated with the newly recognized convergent plate margins gave rise to the radiolarian revolution (Irwin et al. 1977; Ishigaki \& Yao 1982). This was pioneered by researchers such as Pessagno in North America (Pessagno 1976, 1977a, b), Nakaseko and Yao in Japan (e.g. Nakaseko \& Nishimura 1979; Yao et al. 1980) and De Wever (1982) and Baumgartner (1984) in Europe. Aware of the work on late Paleozoic radiolarians that was being carried out by Brian Holdsworth from Keele University, Davey Jones of USGS saw the potential for application of Paleozoic radiolarian biostratigraphy amongst the accretionary terranes of the western US and Alaska (Holdsworth \& Jones 1980).

As we will see in the text below, the same overall picture also holds true for the historical trajectory of studies on Paleozoic radiolarians, as this may be perceived through an analysis of the number of new genera defined yearly (see also the inventory of Paleozoic species, Aitchison et al. 2017b). Our revision of the status of Paleozoic genera (see Caridroit et al. 2017; Noble et al. 2017) takes into account a total of 344 radiolarian genera, for which only 208 (60.5\%) are considered as valid (see Table 1 and Fig. 1). 82 of them $(23.8 \%)$ are regarded as junior synonyms, 35 as nomina dubia (10.2\%), 2 as nomina nuda $(0.6 \%), 7$ genera (2\%) are homonyms, most of the previously homonym names being already replaced, and 10 of them are "not Radiolaria" (2.9\%).

\section{THE GREAT DISCOVERIES OF THE 1890s}

The first Paleozoic radiolarian genera were defined by Hinde (1890) on the basis of material from the Southern Uplands (Scotland, United Kingdom). The presence of radiolarians in these Ordovician cherts was previously announced by Prof. Nicholson of Aberdeen (Nicholson 1889). However, the specimens that he had shown were not convincing for the scientific community. A year later, Hinde (1890) introduced six new genera based on observations made from thin sections of cherts that were collected by Peach during the geological mapping of Scotland. This was a groundbreaking study as it established for the first time that radiolarians existed since the early Paleozoic. Nearly 100 years afterwards, Danelian \& Clarkson (1998), Danelian (1999) and Danelian \& Floyd (2001) succeeded in extracting matrix-free specimens from cherts of the Southern Uplands and attempted to link them to the forms described initially by Hinde.

Hinde (1899a, b) also published two important works on Devonian radiolarians from the Tamworth Belt in northeastern New South Wales, Australia and Cornwall in England. These radiolarians were all described from thin sections. The

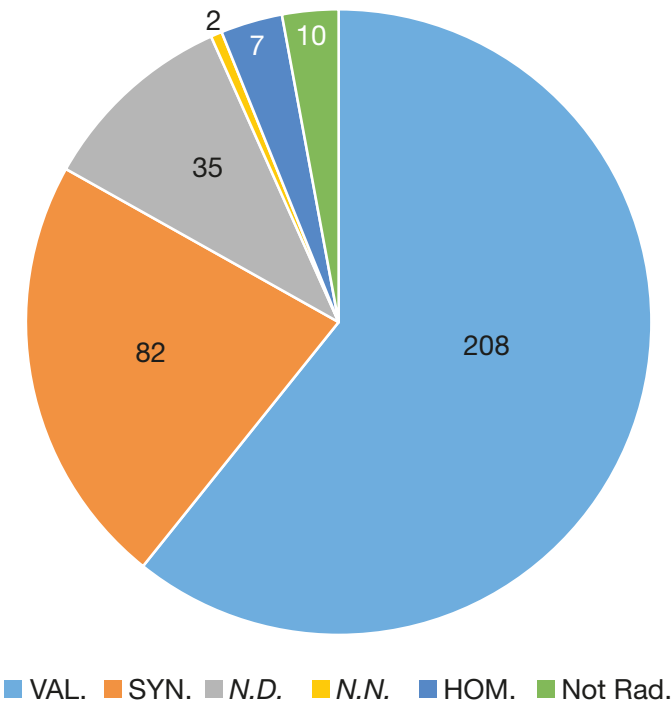

FIG. 1. - Pie chart showing the percentage distribution of 344 Paleozoic genera based on their current taxonomic status: VAL., valid, 208 genera, 60.5\%; SYN., junior synonyms, 82 genera, 23.8\%; N.D., nomina dubia, 35 genera, $10.2 \%$; N.N., nomina nuda, 2 genera, 0.6\%; HOM., homonyms, 7 genera, 2\%; Not Rad., not radiolaria, 10 genera, $2.9 \%$.

New South Wales material was collected by T. W. Edgeworth David (David 1897) and remained in the collections of the University of Sydney for many years. The original thin section blocks were processed to extract matrix-free specimens, which together with the original thin sections are housed in the Museum of Natural History, London, approximately 100 years later (Aitchison \& Stratford 1997).

Hinde's genus Trilonche is an important and abundant component of mid and late Paleozoic assemblages. Regrettably, due in part to the limitations of working with material in thin-section, most of the other genera introduced by Hinde $(1890,1899 \mathrm{a}, \mathrm{b})$ are now considered as nomina dubia and two of them as junior synonyms of Trilonche (see Aitchison \& Stratford 1997; Caridroit et al. 2017; Noble et al. 2017).

\section{IGNORED FOR OVER 50 YEARS DURING THE FIRST HALF OF THE 20TH CENTURY}

As can be seen in Figure 2, with the exception of a single genus (Carposphaeridium) defined by Chapman in 1923, few taxonomic advances were made on Paleozoic radiolarian studies during the first half of the $20^{\text {th }}$ century. The lack of interest amongst the scientific community was possibly compounded by misunderstanding introduced by the uncritical application of the Haeckelian taxonomy, inspired essentially by the study of living forms, to the group's fossil representatives. This was amplified by the "juristic" application by Campbell (1954) of "Copenhagen's Rules of 1953", the basis of the first International Code of Zoological Nomenclature (Hemming 1957). A critical commentary of this problem is presented by Deflandre (1960). 


\begin{tabular}{|c|c|c|c|c|c|c|c|c|c|c|c|c|c|c|c|c|c|}
\hline 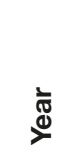 & 을 & $\frac{0}{\underline{3}}$ & $\begin{array}{l}\bar{\varpi} \\
\stackrel{0}{\circ} \\
\end{array}$ & そ̇ & $\stackrel{\circ}{\gtrless}$ & $\frac{i}{z}$ & 온 & 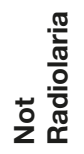 & 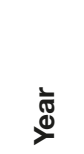 & $\frac{0}{\frac{1}{5}}$ & 을 & $\begin{array}{l}\bar{\pi} \\
\text { 。ㅇ }\end{array}$ & 交 & $\frac{0}{2}$ & $\sum_{z}^{2}$ & 옴 & 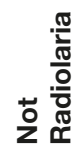 \\
\hline 1890 & - & 6 & 6 & - & 6 & - & - & - & 1953 & 2 & - & 2 & - & - & - & - & - \\
\hline 1891 & - & - & - & - & - & - & - & - & 1954 & - & - & - & - & - & - & - & - \\
\hline 1892 & 1 & - & 1 & - & - & - & - & - & 1955 & - & - & - & - & - & - & - & - \\
\hline 1893 & - & - & - & - & - & - & - & - & 1956 & - & - & - & - & - & - & - & - \\
\hline 1894 & - & - & - & - & - & - & - & - & 1957 & - & - & - & - & - & - & - & - \\
\hline 1895 & - & - & - & - & - & - & - & - & 1958 & 1 & - & 1 & - & - & - & - & - \\
\hline 1896 & - & - & - & - & - & - & - & - & 1959 & - & - & - & - & - & - & - & - \\
\hline 1897 & - & - & - & - & - & - & - & - & 1960 & - & 2 & 2 & - & - & 2 & - & - \\
\hline 1898 & - & - & - & - & - & - & - & - & 1961 & - & - & - & - & - & - & - & - \\
\hline 1899 & 1 & 4 & 5 & 2 & 2 & - & - & - & 1962 & - & - & - & - & - & - & - & - \\
\hline 1900 & - & - & - & - & - & - & - & - & 1963 & 8 & 1 & 9 & 1 & - & - & - & - \\
\hline 1901 & - & - & - & - & - & - & - & - & 1964 & 1 & - & 1 & - & - & - & - & - \\
\hline 1902 & - & - & - & - & - & - & - & - & 1965 & - & - & - & - & - & - & - & - \\
\hline 1903 & - & - & - & - & - & - & - & - & 1966 & - & 3 & 3 & - & 3 & - & - & - \\
\hline 1904 & - & - & - & - & - & - & - & - & 1967 & - & - & - & - & - & - & - & - \\
\hline 1905 & - & - & - & - & - & - & - & - & 1968 & - & - & - & - & - & - & - & - \\
\hline 1906 & - & - & - & - & - & - & - & - & 1969 & - & - & - & - & - & - & - & - \\
\hline 1907 & - & - & - & - & - & - & - & - & 1970 & - & - & - & - & - & - & - & - \\
\hline 1908 & - & - & - & - & - & - & - & - & 1971 & - & - & - & - & - & - & - & - \\
\hline 1909 & - & - & - & - & - & - & - & - & 1972 & 7 & 1 & 8 & 1 & - & - & - & - \\
\hline 1910 & - & - & - & - & - & - & - & - & 1973 & 6 & 5 & 11 & 1 & 3 & - & - & 1 \\
\hline 1911 & - & - & - & - & - & - & - & - & 1974 & - & 1 & 1 & - & 1 & - & - & - \\
\hline 1912 & - & - & - & - & - & - & - & - & 1975 & 2 & 5 & 7 & 4 & 1 & - & - & - \\
\hline 1913 & - & - & - & - & - & - & - & - & 1976 & 3 & 2 & 5 & 1 & - & - & - & 1 \\
\hline 1914 & - & - & - & - & - & - & - & - & 1977 & - & 2 & 2 & - & - & - & - & 2 \\
\hline 1915 & - & - & - & - & - & - & - & - & 1978 & 1 & - & 1 & - & - & - & - & - \\
\hline 1916 & - & - & - & - & - & - & - & - & 1979 & 1 & 1 & 2 & - & 1 & - & - & - \\
\hline 1917 & - & - & - & - & - & - & - & - & 1980 & 4 & 2 & 6 & 2 & - & - & - & - \\
\hline 1918 & - & - & - & - & - & - & - & - & 1981 & 6 & 4 & 10 & 4 & - & - & - & - \\
\hline 1919 & - & - & - & - & - & - & - & - & 1982 & - & - & - & - & - & - & - & - \\
\hline 1920 & - & - & - & - & - & - & - & - & 1983 & 8 & 7 & 15 & 5 & 1 & - & 1 & - \\
\hline 1921 & - & - & - & - & - & - & - & - & 1984 & 8 & 4 & 12 & 3 & - & - & 1 & - \\
\hline 1922 & - & - & - & - & - & - & - & - & 1985 & 10 & 2 & 12 & 2 & - & - & - & - \\
\hline 1923 & - & 1 & 1 & - & 1 & - & - & - & 1986 & 13 & 10 & 23 & 10 & - & - & - & - \\
\hline 1924 & - & - & - & - & - & - & - & - & 1987 & 1 & 4 & 5 & - & - & - & - & 4 \\
\hline 1925 & - & - & - & - & - & - & - & - & 1988 & 5 & 2 & 7 & 2 & - & - & - & - \\
\hline 1926 & - & - & - & - & - & - & - & - & 1989 & 6 & 13 & 19 & 13 & - & - & - & - \\
\hline 1927 & - & - & - & - & - & - & - & - & 1990 & 9 & 6 & 15 & 5 & 1 & - & - & - \\
\hline 1928 & - & - & - & - & - & - & - & - & 1991 & 1 & 2 & 3 & 1 & 1 & - & - & - \\
\hline 1929 & - & - & - & - & - & - & - & - & 1992 & 2 & 1 & 3 & - & 1 & - & - & - \\
\hline 1930 & - & - & - & - & - & - & - & - & 1993 & 3 & 7 & 10 & 3 & 3 & - & - & 1 \\
\hline 1931 & - & - & - & - & - & - & - & - & 1994 & 8 & 3 & 11 & 3 & - & - & - & - \\
\hline 1932 & - & - & - & - & - & - & - & - & 1995 & 3 & 4 & 7 & 1 & 3 & - & - & - \\
\hline 1933 & - & - & - & - & - & - & - & - & 1996 & 5 & 1 & 6 & 1 & - & - & - & - \\
\hline 1934 & - & - & - & - & - & - & - & - & 1997 & 10 & 5 & 15 & 3 & 1 & - & 1 & - \\
\hline 1935 & - & - & - & - & - & - & - & - & 1998 & 4 & 4 & 8 & 3 & - & - & 1 & - \\
\hline 1936 & - & - & - & - & - & - & - & - & 1999 & 7 & 2 & 9 & 2 & - & - & - & - \\
\hline 1937 & - & - & - & - & - & - & - & - & 2000 & 10 & 9 & 19 & 5 & 2 & - & 2 & - \\
\hline 1938 & - & - & - & - & - & - & - & - & 2001 & - & 1 & 1 & 1 & - & - & - & - \\
\hline 1939 & - & - & - & - & - & - & - & - & 2002 & 5 & 2 & 7 & 2 & - & - & - & - \\
\hline 1940 & - & - & - & - & - & - & - & - & 2003 & 1 & - & 1 & - & - & - & - & - \\
\hline 1941 & - & - & - & - & - & - & - & - & 2004 & 2 & - & 2 & - & - & - & - & - \\
\hline 1942 & - & - & - & - & - & - & - & - & 2005 & 2 & - & 2 & - & - & - & - & - \\
\hline 1943 & - & - & - & - & - & - & - & - & 2006 & 7 & 1 & 8 & - & - & - & 1 & - \\
\hline 1944 & - & - & - & - & - & - & - & - & 2007 & 11 & 1 & 12 & 1 & - & - & - & - \\
\hline 1945 & - & - & - & - & - & - & - & - & 2008 & 1 & 5 & 6 & - & 4 & - & - & 1 \\
\hline 1946 & - & - & - & - & - & - & - & - & 2009 & 5 & - & 5 & - & - & - & - & - \\
\hline 1947 & - & - & - & - & - & - & - & - & 2010 & 3 & - & 3 & - & - & - & - & - \\
\hline 1948 & - & - & - & - & - & - & - & - & 2011 & 2 & - & 2 & - & - & - & - & - \\
\hline 1949 & - & - & - & - & - & - & - & - & 2012 & 1 & - & 1 & - & - & - & - & - \\
\hline 1950 & - & - & - & - & - & - & - & - & 2013 & - & - & - & - & - & - & - & - \\
\hline 1951 & - & - & - & - & - & - & - & - & 2014 & 1 & - & 1 & - & - & - & - & - \\
\hline \multirow[t]{2}{*}{1952} & 1 & - & 1 & - & - & - & - & - & 2015 & 7 & - & 7 & - & - & - & - & - \\
\hline & & & & & & & & & 2016 & 2 & - & 2 & - & - & - & - & - \\
\hline
\end{tabular}




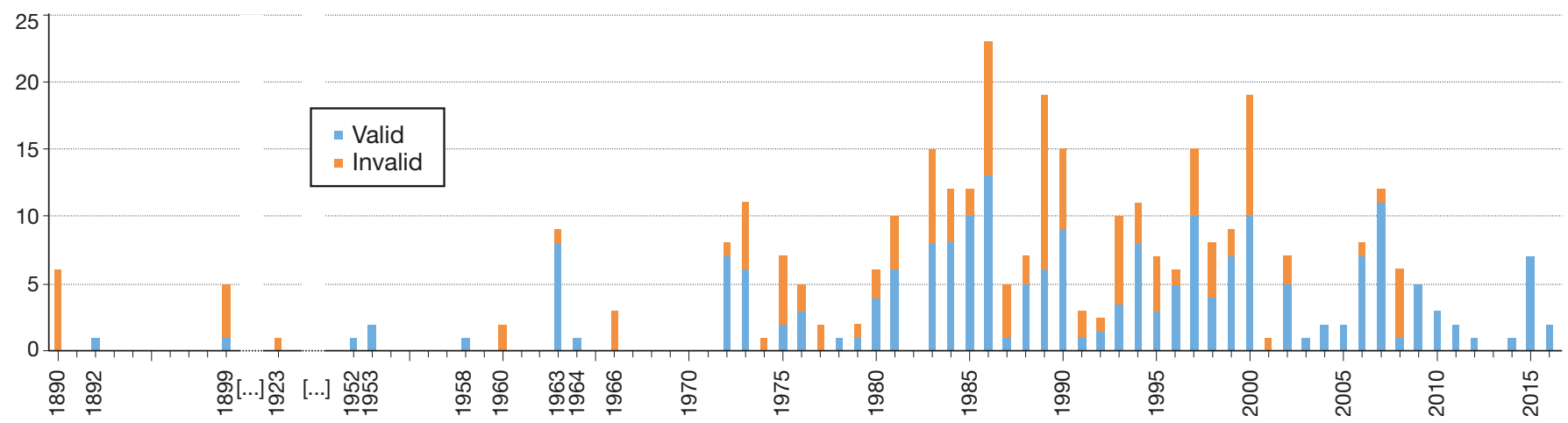

FIG. 2. - Number of new Paleozoic genera introduced yearly since 1890.

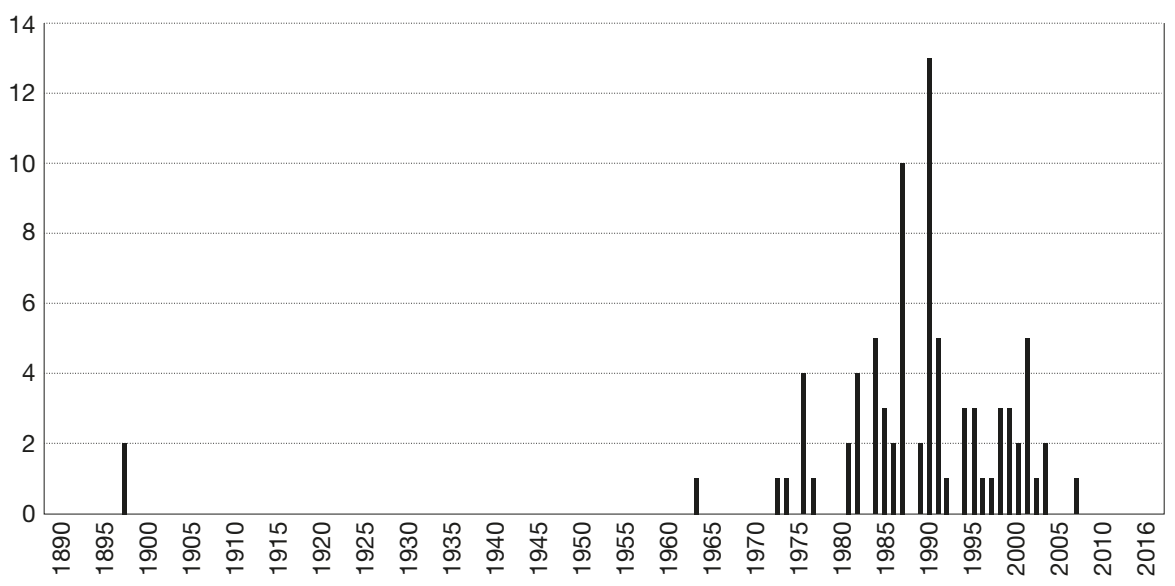

FIG. 3. - Number of synonymised new Paleozoic genera introduced yearly.

\section{0s TO MID 1970s: THE TIME OF RENEWED INTEREST}

In 1952, Deflandre introduced a carefully defined new genus Albaillella, which he immediately recognized as a distinct Carboniferous form unknown from post-Paleozoic sediments and understood the importance of its evolutionary implications. The history behind this discovery is well-described by Caulet (2013). Mr. Albaille, a winemaker from the Montagne Noire area of southern France, whose hobby was Natural History, sent some nodules to the Muséum national d'Histoire naturelle in Paris in order to learn more about their composition. Deflandre, who had been appointed at the Museum since 1930, examined these nodules. The siliceous microfossils that he found in them prompted him in 1940 to pay a visit to $\mathrm{Mr}$ Albaille to obtain a better material. In 1946 he mentioned the discovery of these "unknown" creatures in a short communication of the Comptes Rendus hebdomadaires des Séances de l'Académie des Sciences (Paris). It was not until 1952 that he formally described the type species of Albaillella.

During the period between 1952 and 1973, Deflandre defined 23 new genera as a single author (Deflandre 1952, 1953, 1958, 1960, 1963, 1964, 1972, 1973a, b, c, d) and three others with Ters (Deflandre $\&$ Ters 1966). The majority of them are still considered to be valid and a good number of them are amongst the most important clades of late Paleozoic radiolarians (e.g. Albaillella, Ceratoikiscum, Palaeoscenidium, Lapidopiscum, Pylentonema and Popofskyellum).

Other important contributions to radiolarian genera were made during this period by Brian Holdsworth and Helen Foreman. Although not introducing new genera, important studies by Holdsworth (1966, 1969a, b) on age-correlative strata in England confirmed the widespread occurrence and potential of late Paleozoic radiolarians. In 1959, Helen Foreman reported on the potential of Upper Devonian carbonate nodules from the Ohio Shale to yield a well-preserved radiolarian fauna, from which she later defined eight new genera (Foreman 1963). She paid particular attention to their most internal structures, keeping thus a distance from Haeckelian philosophy of taxonomic classification and adhering to Deflandre's approach.

Around the time of Foreman's work significant contributions at a suprageneric taxonomic level were made. More particularly, the higher-level classification of some radiolarian families by Riedel (1967b) and Petrushevskaya (1971) had a significant contribution to undoing the constraints set by Haeckel and saw the introduction of two important Paleozoic families, the Entactiniidae and Palaeoscenidiidae.

Meanwhile, Boris Nazarov was making significant contributions to radiolarian studies in the USSR, working on materials from throughout the Paleozoic time scale. Initially, his work in Kazakhstan was made on materials from thin section 
(Nazarov 1975a, b), but later work discussed below, especially in partnership with Alan Ormiston, lead to re-analysis of matrix-free material.

\section{LATE 1970s TO 1990s: THE “FAST” YEARS}

The discovery and description in the early 1970s of the dilute hydrofluoric acid (HF) method to extract radiolarians from cherts (Dumitrica 1970; Pessagno \& Newport 1972) opened up the potential for radiolarians to be developed as a valuable biostratigraphic tool for radiolarian chert sequences that commonly occur in complex orogenic zones. During the 1970s, Scanning Electron Microscopes (SEM) became progressively available in geological/paleontological laboratories. Consequently, the common use of the SEM during the late 1970s and early 1980s has had a profound impact on the taxonomic study of Paleozoic radiolarians, in the same way as it has had for the Mesozoic ones. Thus, following the widespread use of the HF method to extract radiolarians from cherts and the routine use of the SEM for the description of their minute structural details, the main driver to conduct taxonomic research on Paleozoic radiolarians was the development of their biostratigraphic potential (see Aitchison et al. 2017a). In Japan, HF methods were independently introduced for conodont research (Hayashi 1968) and since 1967 Yao had managed to extract radiolarians with the use of HF from "Paleozoic" cherts (see Ishigaki \& Yao 1982: 97), although they all turned out to be Mesozoic in age. Thus, the first occurrence report of Paleozoic radiolarians from Japan with an SEM image was delayed until Takemura (1980) in which an illustration of a future "Neoalbaillella" was included.

During the 1970s and 80s, Nazarov in the USSR and Ormiston in the USA played an important role in Paleozoic radiolarian taxonomy, by describing biostratigraphically useful assemblages from the Ordovician through the Permian. Importantly, they established that some of these assemblages were geographically widespread. Nazarov (1973, 1974, 1975b, 1977) and Nazarov \& Popov $(1976,1980)$ introduced fifteen new genera based on type material coming from Kazakhstan and other parts of the former Soviet Union. His monograph on all the valid Paleozoic genera (Nazarov 1988) remains an important reference with this work providing SEM images of many of his genera. He carefully drew the internal structure of many of them, although they are often difficult to observe in his assigned type species. Only three out of the 15 new genera mentioned above are here considered as valid (see Caridroit et al. 2017; Noble et al. 2017); four are treated as nomina dubia, four others as junior synonyms and finally four are now considered to be parts of sponges (Azyrtalia, Konyrium, Anakrusa and Auliela; see Won et al. 2007). Following the study of Ormiston \& Lane (1976), Nazarov \& Ormiston worked together in the 1980s (Nazarov \& Ormiston 1983a, b, 1985, 1986, 1987), and finally in the posthumous paper (Nazarov \& Ormiston 1993), which reviewed many of his career contributions in a biostratigraphic context, and added new genera. Nazarov did not treat middle to upper Permian radiolarians. In practice, Permian radiolarian studies were made possible after the definition of several middle Permian genera such as Follicucullus and Pseudoalbaillella (Ormiston \& Babcock 1979; Holdsworth \& Jones 1980), and the middle-late Permian Neoalbaillella, which was described from cherts of the Jurassic accretionary complex of Japan (Takemura \& Nakaseko 1981).

The 1980s saw an upsurge of new genera introduced owing largely to the wide use of the HF acid method for extracting radiolarians from cherts and the routine use of the SEM for description of their minute structural details. Thus, most descriptive taxonomy papers were made in the context of improving the biostratigraphic resolution of radiolarians (e.g. Ishiga et al. 1982a, b; Cheng 1986, De Wever \& Caridroit 1984). More particularly, based on upper Permian material from the Kamigori belt of SW Japan, De Wever \& Caridroit (1984) defined six new Latentifistularian genera. In the same year Nazarov \& Ormiston (1984) defined six other genera, including the important spumellarians Inanigutta and Inanihella and the archaeospicularian genus Secuicollacta.

An all-time high is recorded in 1986 (Fig. 2) when 23 new genera were formally defined in the literature. However, nearly half of them (10) are now considered as junior synonyms (see Figure 3 and Caridroit et al. 2017; Noble et al. 2017). Most of the new genera introduced in 1986 come from the upper Paleozoic sequences of Oklahoma, such as the 12 genera defined by Cheng (1986) from Upper Devonian to Carboniferous material, although six of them are now regarded as junior synonyms. Three additional new genera were defined ten years later based on material from the same rock succession (Schwartzapfel \& Holdsworth 1996). The study published by Kozur \& Mostler (1989) also represents a substantial contribution towards Lower Permian radiolarian taxonomy; however, out of the nineteen new genera defined by these authors, thirteen are now considered as junior synonyms (see Figure 3 and De Wever et al. 2001; Caridroit et al. 2017; Noble et al. 2017). In the words of Dumitrica \& Aita (2017) Kozur and Mostler were "great splitters, producing thus a large number of synonyms".

Work lower in the timescale, particularly on Ordovician through Middle Devonian assemblages, was underway in the 1980s and 1990s. Unique palaeosceniid genera with a cortical shell (Pactarentactinia and Tlecerina) were defined based on material from the Lower Devonian Nakahata Formation of the Kurosegawa terrane (Japan; Furutani 1983). Seven new upper Silurian and Lower Devonian genera were further defined from the Yoshiki and Hitoegane Formations of the Hida-gaien Belt (Furutani 1990) and four others from the Yokokurayama Group (Wakamatsu et al. 1990). With the exception of Nazaromistonella all these genera are still regarded as valid. In addition to occurrences in Japan, they have been found also in North America and Europe.

The late 1980s and 90s saw also the introduction of the genus Protoceratoikiscum, defined based on material ex- 
tracted from Ordovician cherts of the Lachlan Fold Belt (eastern Australia; Goto et al. 1992), the Late Ordovician genus Kalimnasphaera (Webby \& Blom 1986) and the Early Ordovician genus Beothuka from Newfoundland (Aitchison et al. 1998). The lower Paleozoic family Proventocitidae was established by Aitchison (1998) based on material reported from Scotland, Spitsbergen and Russia (the original spelling Proventocitiidae, which applied an incorrectly formed suffix was corrected to Proventocitidae in De Wever et al. 2001).

In North America, eleven new Silurian genera were introduced based on material extracted from carbonate nodules of the Canadian Archipelago (Goodbody 1986; Mac Donald 1998, 1999, 2006; Jones \& Noble 2006) and six others by Noble (1994) from the Marathon uplift in west Texas. Working at the same time on similar Devonian-aged rocks but on different continents, Aitchison (1993) and Feng \& Liu (1993) introduced Paraholoeciscus and Eoalbaillella, respectively and synonyms thereof. In detailed studies of exceptionally well preserved material from the Upper Devonian Gogo Formation of Western Australia Won (1997a, b) introduced a total of 20 new genera. By the mid 1980s, the SEM was routinely used in micropaleontological studies in China and gave the opportunity to define new genera based on material from Permian (Sheng \& Wang 1985; Feng \& Liu 1993; Wang 1995), as well as Ordovician and Silurian strata (Li 1994, 1995). However, the quality of images provided was sometimes unsatisfactory and made evaluation of their taxonomic validity difficult (e.g. Longtanella).

\section{THE EARLY 21ST CENTURY QUEST FOR THE OLDEST AND SIGNIFICANT PROGRESS IN THE LATE PERMIAN}

The description by Won \& Below (1999) of well-preserved Middle Cambrian radiolarians from Australia, in which they defined six new genera, created the perception of a wide breadth of distinct structural features of primitive radiolarians and help us discard controversial material from China (Maletz 2017). Subsequent description by Won $\&$ Iams (2002) of upper Cambrian radiolarians from western Newfoundland was equally paramount, as the pelagic limestones of the Cow Head Group have become a key for understanding the radiolarian evolution and faunal changes throughout the Late Cambrian-Early Ordovician interval (Won et al. 2005, 2007; Pouille et al. 2014). Generally speaking, interest in the early Paleozoic diversity and evolution of radiolarians was the main driver for the increase of the number of new radiolarian genera for the last two decades. Amongst the 68 valid genera defined since 1999, thirty six of them concern Cambrian and Ordovician radiolarians (Aitchison et al. 1998; Won \& Below 1999; Obut \& Iwata 2000; Won \& Iams 2002, 2011, 2015; Danelian \& Popov 2003; Maletz \& Bruton 2005, 2007; Won et al. 2005, 2007).

This century has also seen continuing work on Devonian radiolarians with Afansieva and colleagues describing various genera that mostly come from the well-preserved faunas recovered from the Domanik-facies in Russia (e.g. Afanasieva 2000).

Interest in improving our understanding of the radiolarian biotic response during the Permian-Triassic mass extinction event has stimulated high quality taxonomic research on late Permian radiolarians. Until the turn of the $20^{\text {th }}$ century, Permian radiolarian genera were often defined based on faunas that were generally of medium to poor preservation. More recently, extremely well-preserved radiolarians have been described and illustrated from the uppermost Permian Dalong Formation in South China (Feng et al. 2004, 2006a, b, 2007a, b), with special attention being paid to adequate documentation and illustration of their internal structure. Thus, the genus level taxonomy of Latentifistularian radiolarians was revised based on observations on well-preserved specimens (Feng et al. 2007b). This century is expected to allow the development of a classification system that better reflects natural phylogenetic relationships.

\section{Acknowledgements}

We are grateful to Patrick De Wever and Jean-Pierre Caulet for their review remarks. JA acknowledges financial support towards investigation of Early Paleozoic radiolarian evolution in the form of a grant from the Australian Research Council (ARC DP 1501013325).

\section{REFERENCES}

Afanasieva M. S. 2000. - New radiolarians of the superfamily Entactinoidea from the Upper Devonian of Timan-Pechora Province, Russia. Paleontological Journal 34 (2): 131-146.

Aitchison J. C. 1993. - Albaillellaria from the New England orogen, Eastern NSW, Australia. Marine Micropaleontology 21 (4):353-367. https://doi.org/10.1016/0377-8398(93)90026-T

AITCHISON J. C. 1998. - A Lower Ordovician (Arenig) radiolarian fauna from the Ballantrae Complex, Scotland. Scottish Journal of Geology 34 (1): 73-81. https://doi.org/10.1144/sjg34010073

Aitchison J. C. \& STRATFord J. M. C. 1997. — Middle Devonian (Givetian) Radiolaria from eastern New South Wales, Australia; a reassessment of the Hinde (1899) fauna. Neues Jahrbuch für Geologie und Paläontologie, Abhandlungen 203: 369-390.

Aitchison J. C., Flood P. G. \& Malpas J. 1998. — Lowermost Ordovician (basal Tremadoc) radiolarians from the Little Port Complex, western Newfoundland (Lower Ordovician radiolarians, Newfoundland). Geological Magazine 135: 413-419. https:// doi.org/10.1017/S001675689800867X

Aitchison J. C., Suzuki N., Caridroit M., Danelian T. \& Noble P. 2017a. - Paleozoic radiolarian biostratigraphy, in DANELIAN T., CARidroit M., Noble P. \& Aitchison J. C. (eds), Catalogue of Paleozoic radiolarian genera. Geodiversitas 39 (3): 503-531 (this issue). https://doi.org/10.5252/g2017n3a5

Aitchison J. C., SuZuki N. \& O’DOGHerTy L. 2017b. — Inventory of Paleozoic radiolarian species (1880-2016), in DANELIAN T., Caridroit M., Noble P. \& Aitchison J. C. (eds), Catalogue of Paleozoic radiolarian genera. Geodiversitas 39 (3): 533-637 (this issue). https://doi.org/10.5252/g2017n3a6

BaumgarTnER P. O. 1984. - A Middle Jurassic-Early Cretaceous low latitude radiolarian zonation based on unitary associations and age of Tethyan radiolarites. Eclogae Geologicae Helvetiae 77 (3): 729-841. 
Campbell A. S. 1954. — Radiolaria, in Moore R. C. (ed.), Treatise on Invertebrate Paleontology. Geological Society of America and University of Kansas Press, Lawrence, Kansas : 11-195.

Caridroit M. \& De Wever P. 1984. - Description de quelques nouvelles espèces de Follicucullidae et d'Entactinidae (Radiolaires polycystines) du Permien du Japon. Geobios 17 (5): 639-644. https://doi.org/10.1016/S0016-6995(84)80035-2

Caridroit M., Danelian T., O’Dogherty L., Cuvelier J. C., Aitchison J., Pouille L., Noble P., Dumitrica P., Suzuki N., Kuwahara K., Maletz J. \& Feng Q. 2017. — An illustrated catalogue and revised classification of Paleozoic radiolarian genera, in Danelian T., Caridroit M., Noble P. \& Aitchison J. C. (eds), Catalogue of Paleozoic radiolarian genera. Geodiversitas 39 (3): 363-417 (this issue). https://doi.org/10.5252/g2017n3a3

CAulet J.-P. 2013. — Georges Deflandre (March 18th, 1897, Dizy Magenta (Marne) - June 17th, 1973, Paris). The first French naturalist interested in siliceous microfossils. Revue de Micropaléontologie 56: 45-50. https://doi.org/10.1016/j.revmic.2013.04.001

ChAPMAN F. 1923. - Report on fossils from an Upper Cambrian horizon at Loyola, near Mansfield. Bulletin of the Geological Survey of Victoria 64: 34-45.

Cheng Y.-N. 1986. - Taxonomic Studies on Upper Paleozoic Radiolaria. National Museum of natural Science, Taiwan, special Publication 1: 1-310.

DANELIAN T. 1999. - Taxonomic study of some Ordovician (Llanvirn-Caradoc) radiolaria from the Southern Uplands (Scotland, U.K.). Geodiversitas 21 (4): 625-635.

Danelian T. \& Clarkson E. N. K. 1998. —Middle Ordovician Radiolaria from bedded cherts of the Southern Uplands. Scottish Journal of Geology 34 (2): 133-137. https://doi.org/10.1144/ sig34020133

DANelian T. \& Floyd J. 2001. - Progress in describing Ordovician siliceous biodiversity from the Southern Uplands (Scotland, U.K.). Transactions of the Royal Society of Edinburgh, Earth Sciences 91: 489-498. https://doi.org/10.1017/S0263593300008336

DANELIAN T. \& POPOV L. 2003. — Ordovician radiolarian biodiversity: insights based on new and revised data from Kazakhstan. Bulletin de la Société géologique de France 174 (4): 325-335. https:// doi.org/10.2113/174.4.325

DAVID T. W. E. 1897. - The occurrence of Radiolaria in Paleozoic rocks in N. S. Wales. Proceedings of the Linnean Society of New South Wales 21: 553-570. https://doi.org/10.5962/bhl.part.8484

DeFlandRE G. 1946. - Radiolaires et Hystrichosphaeridés du Carbonifere de la Montagne noire. Comptes Rendus hebdomadaires des Séances de l'Académie des Sciences (Paris), Série D: Sciences Naturelles 223: 515-517. http://gallica.bnf.fr/ark:/12148/bpt6k31759

DEFLANDRE G. 1952. - Albaillella nov. gen., radiolaire fossile du Carbonifere inférieur, type d'une lignée aberrante éteinte. Comptes Rendus hebdomadaires des Séances de l'Académie des Sciences (Paris), Série D: Sciences naturelles 234: 872-874. http://gallica.bnf.fr/ ark:/12148/bpt6k3186w

Deflandre G. 1953. - Radiolaires fossiles, in Grassé P. P. (ed.), Traité de Zoologie. Masson, Paris: 389-436.

DeFLANDRE G. 1958. — Lapidopiscum nov. gen., type nouveau de Radiolaire viséen, famille des Lapidopiscidae fam. nov., de l'ordre des Albaillellidae Defl. 1953. Comptes Rendus hebdomadaires des Séances de l'Académie des Sciences (Paris), Série D: Sciences naturelles 246: 2278-2280. http://gallica.bnf.fr/ark:/12148/bpt6k723q

DeFlandre G. 1960. - À propos du développement des recherches sur les Radiolaires fossiles. Revue de Micropaléontologie 2 (4): 212-218.

Deflandre G. 1963. - Pylentonema, nouveau genre de Radiolaire du Viséen: Sphaerellaire ou Nassellaire? Comptes Rendus hebdomadaires des Séances de l'Académie des Sciences (Paris), Série D: Sciences naturelles 257: 3981-3984. http://gallica.bnf.fr/ ark:/12148/bpt6k4009k

DeflandRE G. 1964. — La famille des Popofskyellidae fam. nov. et le genre Popofskyellum Defl., Radiolaires viséens de la Montagne
Noire. Comptes Rendus hebdomadaires des Séances de l'Académie des Sciences (Paris), Série D: Sciences naturelles 259: 3055-3058. http://gallica.bnf.fr/ark:/12148/bpt6k4015m

DEFLANDRE G. 1972. — Remarques complémentaires sur la morphologie et la nomenclature de quelques genres de Radiolaires du Paléozoïque. Comptes Rendus hebdomadaires des Séances de l'Académie des Sciences (Paris), Série D: Sciences naturelles 275 (1): 13-16. http://gallica.bnf.fr/ark:/12148/bpt6k57786873

DEFLANDRE G. 1973a. — Observations et remarques sur les Radiolaires Sphaerellaires du Paléozoïque, à propos d'une nouvelle espece, viséenne, du genre Foremaniella Defl., parfait intermediaire entre les Périaxoplastidiés et les Pylentonémidés. Comptes Rendus hebdomadaires des Séances de l'Académie des Sciences (Paris), Série D: Sciences naturelles 276 (1): 1147-1151. http://gallica.bnf.fr/ ark:/12148/bpt6k5803214k

DEFLANDRE G. 1973b. - Sur quelques nouveaux types de Radiolaires Polycystines viséens, d'attribution systématique ambiguë, certains évoquant à la fois des Plectellaires et des Spumellaires. Comptes Rendus hebdomadaires des Séances de l'Académie des Sciences (Paris), Série D: Sciences naturelles 276 (2): 289-293. http:// gallica.bnf.fr/ark:/12148/bpt6k5803214k

DEFLANDRE G. 1973c. — Compléments historiques et taxinomiques sur les Radiolaires viséens. Remarques critiques sur les Plectellaires. Comptes Rendus hebdomadaires des Séances de l'Académie des Sciences (Paris), Série D: Sciences naturelles 276 (1): 497-500. http://gallica.bnf.fr/ark:/12148/bpt6k5803214k

DefLANDRE G. 1973d. - Sur quelques nouvelles espèces d'Archocyrtium, radiolaires Pylentonemidae du Viséen de Cabrières. Comptes Rendus hebdomadaires des Séances de l'Académie des Sciences (Paris), Série D: Sciences naturelles 277: 149-152. http:// gallica.bnf.fr/ark:/12148/bpt6k5474901n

Deflandre G. \& Ters M. 1966. — Sur l'âge cambro-silurien des terrains anciens de la Vendée littorale (ex-Briovérien). Comptes Rendus hebdomadaires des Séances de l'Académie des Sciences (Paris), Série D: Sciences naturelles 262: 339-452. http://gallica.bnf.fr/ ark:/12148/bpt6k5489696x

De Wever P. 1982. - Radiolaires du Trias et du Lias de la Téthys (Systématique, Stratigraphie). Société géologique du Nord 7 (2): $599 \mathrm{p}$.

De WeVEr P. \& Caridroit M. 1984. - Description de quelques nouveaux Latentifistulidae (radiolaires polycystines) Paléozoïques du Japon. Revue de Micropaléontologie 27 (2): 98-106.

De Wever P., Dumitrica P., Caulet J.-P., Nigrini C. \& CariDROIT M. 2001. - Radiolarians in the Sedimentary Record. Gordon \& Breach Science Publishers, Amsterdam, 533 p.

DumitRICA P. 1970. - Cryptocephalic and cryptothoracic Nassellaria in some Mesooic deposits of Romania. Revue roumaine de Géologie, Géophysique et Géographie (série Géologie) 14 (1): 45-124.

DuMITRICA P. \& AITA Y. 2017. - Progress on Triassic radiolarian taxonomy: in memory of Heinz Kozur and Helfried Mostler. Revue de Micropaléontologie 60 (1):3-6. https://doi.org/10.1016/j. revmic.2017.03.003

FENG Q. \& LiU B. 1993. - Radiolarian from late Permian and early-middle Triassic in Southwest Yunnan. Earth Science, Journal of China University of Geosciences 18 (5): 552-563.

FEng Q., Gu S., Jian M. \& Jin Y. 2004. — Two new genera of Radiolaria from the uppermost Permian of South China. Revue de Micropaléontologie 47: 135-143. https://doi.org/10.1016/ S0035-1598(04)00033-9

Feng Q., He W., Gu S., Jin Y. \& Meng Y. 2006a. — Latest Permian Spumellaria and Entactinaria (Radiolaria) from South China. Revue de Micropaléontologie 49: 21-43. https://doi.org/10.1016/j. revmic.2005.11.003

Feng Q., He W., Zhang S. \& Gu S. 2006b. — Taxonomy of Order Latentifistularia (Radiolaria) from the latest Permian in Southern Guangxi, China. Journal of Paleontology 80: 826-848. https:// doi.org/10.1666/0022-3360(2006)80[826:TOOLRF]2.0.CO;2 Feng Q., Gu S., He W. \& Jin Y. 2007a. — Latest Permian Entac- 
tinaria (Radiolaria) from southern Guangxi, China. Journal of Micropalacontology 26: 19-37. https://doi.org/10.1144/jm.26.1.19

Feng Q., Meng Y., He W. \& Gu S. 2007b. - A new genus of Entactiniidae (Radiolaria) from the Upper Permian of South China. Eclogae Geologicae Helvetiae 99 (supplement 1): 67-78.

FOREMAN H. P. 1959. - A new occurrence of Devonian Radiolaria in calcareous concretions of the Huron member of the Ohio shale. Journal of Paleontology 33 (1): 76-80. http://www.jstor. org/stable/1300810

FOREMAN H. P. 1963. - Upper Devonian Radiolaria from the Huron member of the Ohio shale. Micropaleontology 9 (3): 267 304. https://doi.org/10.2307/1484751

FURUTANI H. 1983. — Middle Palaeozoic Palaeoscenidiidae (Radiolaria) from Mt. Yokokura, Shikoku, Japan. Part 1. Transcations and Proceedings of the Palaeontological Society of Japan, new Series 130: 96-116.

Furutani H. 1990. — Middle Paleozoic radiolarians from Fukuji Area, Gifu Prefecture, central Japan. Journal of Earth Sciences Nagoya University 37: 1-56.

GoodBody Q. H. 1986. - Wenlock Palaeoscenidiidae and Entactiniidae (Radiolaria) from the Cape Phillips Formation of the Canadian Arctic Archipelago. Micropaleontology 32: 129-157. https://doi.org/10.2307/1485627

Goto H., Umeda M. \& Ishiga H. 1992. — Late Ordovician Radiolarians from the Lachlan Fold Belt, Southeastern Australia. Memoirs of the Faculty of Science, Shimane University 26: 145-170.

HAECKEL E. 1887. - Report on the Radiolaria collected by H.M.S. Challenger during the years 1873-1876. Report on the Scientific Results of the Voyage of the H.M.S. Challenger, Zoology 18: clxxxviii + 1803. https://doi.org/10.5962/bhl.title.6513

HAYASHI S. 1968. - The Permian conodonts in chert of the Adoyama Formation, central Japan. Earth Science (Chikyu Kagaku), 22: 63-77 (in Japanese with English abstract).

Hemming F. (ed.) 1957. - Opinions and Declarations Rendered by the International Commission on Zoological Nomenclature. International Trust for Zological Nomenclature, London, $530 \mathrm{p}$.

Hinde G. J. 1890. — Notes on Radiolaria from the Lower Palaeozoic rocks (Llandeilo-Caradoc) of the South of Scotland. Annals and Magazine of Natural History, sixth series, 6: 40-59. https:// doi.org/10.1080/00222939008693993

HINDE G. J. 1899a. - On the Radiolaria in the Devonian rocks of New South Wales. Quarterly Journal of the Geological Society of London 55: 38-64. https://doi.org/10.1144/GSL.JGS.1899.055.01-04.06

HindE G. J. 1899b. - On Radiolaria in chert from Chypons Farm, Mullion Parish (Cornwall). Quarterly Journal of the Geological Society of London 55: 214-219. https://doi.org/10.1144/GSL. JGS.1899.055.01-04.14

HoldswORTH B. K. 1966. - Radiolaria from the Namurian of Derbyshire. Palaeontology 9: 319-329.

HoldSWORTH B. K. 1969a. - Namurian Radiolaria of the genus Ceratoikiscum from Stafford and Derbyshire, England. Micropaleontology 15: 221-229. https://doi.org/10.2307/1484921

HOLDSWORTH B. K. 1969b. - The relationship between the genus Albailella Deflandre and ceratoikiscid Radiolaria. Micropaleontology 15: 230-236. https://doi.org/10.2307/1484922

HoldSWORTH B. K. \& Jones D. L. 1980. — Preliminary radiolarian zonation for late Devonian through Permian time. Geology 8: 281-285. https://doi.org/10.1130/0091-7613(1980)8\%3C281 :PRZFLD\%3E2.0.CO;2

ICHIKAWA K. 1982. - History of paleontology on Mesozoic and Paleozoic radiolarians in Japan. News of Osaka Micropaleontologists, spec. vol. 5: 1-9 (in Japanese with English abstract).

IrWIN W. P., Jones D. L. \& PeSSAgno E. A. JR 1977. — Significance of Mesozoic radiolarians from the pre-Nevadan rocks of the southern Klamath Mountains, California. Geology 5: 557-562. https:// doi.org/10.1130/0091-7613(1977)5<557:SOMRFT>2.0.CO;2

Ishiga H., Kito T. \& Iмото N. 1982a. — Late Permian radiolarian assemblages in the Tamba District and an adjacent area,
Southwest Japan. Earth Science, Journal of the Association for the Geological Collaboration in Japan 36 (1): 10-22.

Ishiga H., Kito T. \& Imoto N. 1982b. — Middle Permian radiolarian assemblages in the Tamba district and adjacent area, Southwest Japan. Earth Science, Journal of the Association for the Geological Collaboration in Japan 36 (1): 272-281.

ISHIGAKI K. \& YAO A. 1982. - Radiolarian revolution - conversation with a radiolarian researcher and a teacher of Earth Sciences. Education of Earth Sciences and Scientific Movement 11: 93-102 (in Japanese).

Jones M. K. \& Noble P. J. 2006. - Sheinwoodian (uppermost Lower Silurian) Radiolaria from the Cape Phillips Formation, Nunavut, Canada. Micropaleontology 52: 289-315. https://doi. org/10.2113/gsmicropal.52.4.289

KOZUR H. \& MOSTLER H. 1989. — Radiolarien und schwammskleren aus dem Unterperm des Vorurals. Geologisch Paläontologische Mitteilungen Innsbruck, Sonderband 2: 147-275.

Li H. S. 1994. - Middle Silurian radiolarians from Keerhada, Xinjiang. Acta Micropalaeontologica Sinica 11: 259-272

Li H. S. 1995. - New genera and species of middle Ordovician Nassellaria and Albaillellaria from Baijingsi, Quilian Mountains, China. Scientia Geologica Sinica 4: 331-346.

MacDonald E. W. 1998. - Llandovery Secuicollactinae and Rotasphaeridae (Radiolaria) from the Cape Phillips Formation, Cornwallis Island, Arctic Canada. Journal of Paleontology 72: 585-604. https://doi.org/10.1017/S0022336000040324

MacDonald E. W. 1999. - Insolitignum n.gen. and Palaeoephippium Goodbody 1986 (Radiolaria) from the Lower Silurian of the Cape Phillips Formation, Arctic Canada. Canadian Journal of Earth Sciences 36 (12): 2051-2057. https://doi.org/10.1139/e99-101

MACDONALD E. W. 2006. - A preliminary radiolarian biozonation for the Lower Silurian of the Cape Phillips Formation, Nunavut, Canada. Canadian Journal of Earth Sciences 43: 205-211. https:// doi.org/10.1139/e05-104

MALETZ J. 2017. - The identification of putative Lower Cambrian Radiolaria. Revue de Micropaléontologie 60: 233-240. https://doi. org/10.1016/j.revmic.2017.04.001

Maletz J. \& BRUTON D. L. 2005. - The Beothuka terranova (Radiolaria) assemblage and its importance for the understanding of early Ordovician radiolarian evolution. Geological Magazine 142: 711-721. https://doi.org/10.1017/S0016756805001391

MaletZ J. \& BRUTON D. L. 2007. - Lower Ordovician (Chewtonian to Castlemainian) radiolarians of Spitsbergen. Journal of Systematic Palaeontology 5: 245-288. https://doi.org/10.1017/ S1477201907002039

NAGAI H. 1995. - History and significance of radiolarian biostratigraphic study on the Mesozoic of the Mino Terrane. Bulletin of the Nagoya University Furukawa Museum 4: 1-89 (in Japanese with English abstract).

NAKASEKO K. \& Nishimura A. 1979. - New information on the radiolarian fossils from the Shimanto Group. News of Osaka Micropaleontologists 7: 27-47 (in Japanese).

NAZAROV B. B. 1973. - Radiolarians from the Lower Cambrian of the Batenev Ridge, in Zhuravleva I. T. (ed.), Problems of paleontology and biostratigraphy of the Lower Cambrian of Siberia and Russian Far East. Transactions of the Institute of Geology and Geophysics, Academy of Science of the USSR, Siberian Branch 49: 5-13.

NAZAROV B. B. 1974. - The problematic siliceous formation from the Lower Paleozoic of Kazakhstan. Transactions of the Geological Institute of the Soviet Akademy of Sciences 226: 110-113.

NAZAROv B. B. 1975a. - On the systematics of Paleozoic Sphaeroids, in ZHAMOIDA A. I. (ed.), Systematics and Stratigraphic Importance of Radiolaria. Publication of the All-Union Institute of Geology, new series, Leningrad, USSR: 35-40.

NaZArov B. B. 1975b. - Lower and Middle Paleozoic radiolarians of Kazakhstan (research methods, systematics, stratigraphic importance). Transactions of the Academy of Sciences of the USSR, 
Geological Institute 275: 1-203 p.

NAZAROV B. B. 1977. — Novoe Semeystvo radiolyariy iz Ordovika Kazakhstana [A new radiolarian family from the Ordovician of Kazakhstan]. Paleontological Journal 2: 35-41.

Nazarov B. B. 1988. - Paleozoic Radiolaria, Practical Manual of Microfauna of the USSR. Radiolyarii Paleozoy. Nedra, Leningrad, $232 \mathrm{p}$.

NAZAROV B. B. \& POPOV L. Y. 1976. — Radiolarians, Inarticulate Brachiopods and organisms of uncertain systematic position from the Middle Ordovician of Eastern Kazakhstan. Paleontological Journal 4: 407-416.

NaZAROV B. B. \& Popov L. Y. 1980. - Stratigraphy and fauna of the siliceous-carbonate sequence of the Ordovician of Kazakhstan (Radiolaria and inarticulate brachiopods). Transactions of the Geological Institute of the Soviet Akademy of Sciences 331: 1-192.

Nazarov B. B. \& Ormiston A. 1983a. - Upper Devonian (Frasnian) radiolarian fauna from the Gogo Formation, Western Australia. Micropaleontology 29 (4): 454-466. https://doi. org/10.2307/1485519

NaZAROV B. B. \& Ormiston A. 1983b. - A new superfamily of stauraxon polycystine Radiolaria from the Late Paleozoic of the Soviet Union and North America. Senckenbergiana Lethaea 64: 363-379.

NazAROV B. B. \& Ormiston A. 1984. - Tentative system of Paleozoic Radiolaria, in Petrushevskaya M. G. \& Stepanjants S. D. (eds), Morphology, Ecology and Evolution of Radiolarians. Material from the IV symposium of European radiolarists EURORAD IV. Academy of Sciences of the U.S.S.R., Zoological Institute, 64-87.

Nazarov B. B. \& Ormiston A. R. 1985. - Radiolaria from the Late Paleozoic of the Southern Urals, USSR and West Texas, USA. Micropaleontology 31 (1): 1-54. https://doi.org/10.2307/1485579

NazAROV B. B. \& Ormiston A. R. 1986. - Origin and biostratigraphic potential of the stauraxon polycystine Radiolaria. Marine Micropaleontology 11 (1-3): 33-54. https://doi.org/10.1016/03778398(86)90004-6

Nazarov B. B. \& Ormiston A. R. 1987. - A new Carboniferous radiolarian genus and its relation to the multishelled entactiniids. Micropaleontology 33 (1): 66-73. https://doi.org/10.2307/1485527

NAZAROV B. B. \& ORMISTON A. R. 1993. - New biostratigraphically important Paleozoic Radiolaria of Eurasia and North America, in Blueford J. R. \& MuRChEY B. L. (eds), Radiolaria of Giant and Subgiant Fields in Asia. Nazarov Memorial Volume. Micropaleontology, Special Publication 6: 22-60.

Nicholson H. A. 1889. - Address on Recent Progress in Palaeontology as regards Invertebrate Animals. Transactions of the Edinburgh Geological Society 6: 53-69. https://doi.org/10.1144/ transed.6.1.53

Noble P. J. 1994. - Silurian Radiolarian Zonation for the Caballos Novaculite, Marathon Uplift, West Texas. Bulletins of American Paleontology 106 (2): 1-55. http://biodiversitylibrary.org/ page/ 10684913

Noble P., Aitchison J., Danelian T., Dumitrica P., Maletz J., Suzuki N., Caridroit M., O’Dogherty L. \& Cuvelier J. C. 2017. - Taxonomy of Paleozoic radiolarian genera, in DANElian T., Caridroit M., Noble P. \& Aitchison J. C. (eds), Catalogue of Paleozoic radiolarian genera. Geodiversitas 39 (3): 419-502 (this issue). https://doi.org/10.5252/g2017n3a4

OBut O. T. \& IwATA K. 2000. - Lower Cambrian Radiolaria from the Gorny Altai (southern West Siberia). Novosti Paleontologii $i$ Stratigrafii 2-3: 33-37.

O’Dogherty L., De WeVer P., GoriČan Š. 2009. — Historical perspective: 140 years of Mesozoic radiolarian taxonomy. Geodiversitas 31 (2): 357-369. https://doi.org/10.5252/g2009n2a5

Ormiston A. R. \& LANE H. R. 1976. - A unique radiolarian fauna from the Sycamore Limestone (Mississippian) and its biostratigraphic significance. Palaeontographica. Abteilung A: Palaozoologie-Stratigraphie 154: 158-180.

ORMISTON A. \& BABCOCK L. 1979. - Follicucullus, new radiolarian genus from the Guadalupian (Permian) Lamar limestone of the
Delaware Basin. Journal of Paleontology 53 (2): 328-334. http:// www.jstor.org/stable/1303874

PESSAGNO E. A. 1976. - Radiolarian zonation and stratigraphy of the Upper Cretaceous portion of the Great Valley Sequence, California Coast Ranges. Micropaleontology, Special Publication 2, 95 p.

PESSAGNO E. A. 1977a. - Upper Jurassic Radiolaria and radiolarian biostratigraphy of the California Coast Ranges. Micropaleontology 23 (1): 56-113. https://doi.org/10.2307/1485310

Pessagno E. A. 1977b. - Lower Cretaceous radiolarian biostratigraphy of the Great Valley Sequence and Franciscan Complex, California Coast Ranges. Cushman Foundation for Foraminiferal Research, Special Publication 15: 1-87.

Pessagno E. A. \& NEWPORT R. L. 1972. — A technique for extracting Radiolaria from radiolarian cherts. Micropaleontology 18 (2): 231-234. https://doi.org/10.2307/1484997

PetrusheVsKaya M. G. 1971. - Radiolarians of the Ocean. Reports on the Soviet Expeditions. Academy of Sciences of the U.S.S.R., Zoological Institute, Explorations of the Fauna of the Seas 9 (17): 294 p. (in Russian).

Pouille L., DANELIAN T. \& MALETZ J. 2014. — Radiolarian diversity changes during the Late Cambrian-Early Ordovician transition as recorded in the Cow Head Group of Newfoundland (Canada). Marine Micropaleontology 110: 25-41. https://doi.org/10.1016/j. marmicro.2013.05.002

RIEDEL W. R. 1967a. - Radiolarian evidence consistent with spreading of the Pacific floor. Science 157 (3788): 540-542. https://doi org/10.1126/science.157.3788.540

Riedel W. R. 1967b. - Subclass Radiolaria, in HarLand W. B. et al. (eds), The Fossil Record. A Symposium with Documentation. Geological Society of London, London: 291-298.

RIEDEL W. R. \& HAYS J. D. 1969. - Cenozoic Radiolaria from Leg 1, in Initial Reports of the Deep Sea Drilling Project. U.S. Government Printing Office, Washington, DC 1: 400-402. https://doi.org/10.2973/dsdp.proc.1.119.1969

RIEDEL W. R. \& SANFILIPPO A. 1974. - Radiolaria from the southern Indian Ocean, DSDP Leg 26, in Initial Reports of the Deep Sea Drilling Project. U.S. Government Printing Office, Washington, DC 26: 771-814. https://doi.org/10.2973/dsdp. proc.26.133.1974

SCHWARTZAPFEL J. A. \& HOLDSWORTH B. K. 1996. - Upper Devonian and Mississippian radiolarian zonation and biostratigraphy of the Woodford, Sycamore, Caney and Goddard Formations, Oklahoma. Cushman Foundation for Foraminiferal Research, Special Publication 33: 1-275.

SHENG J. Z. \& WANG Y. J. 1985. - Fossil Radiolaria from Kufeng Formation at Longtan, Nanjing. Acta Palaeontologica Sinica 24 (2): 171-183.

Takemura A. 1980. - The Paleo-Mesozoic system of the Tamba Belt in the southern part of Kameoka City, Kyoto Prefecture, Japan. News of Osaka Micropaleontologists 8: 22-31 (in Japanese with English title).

TAKemura A. \& NAKaseko K. 1981. — A new Permian radiolarian genus from the Tamba Belt, Southwest Japan. Transactions and Proceedings of the Palaeontological Society of Japan, New Series 124: 208-214. https://doi.org/10.14825/prpsj1951.1981.124_208

Wakamatsu H., Sugiyama K. \& Furutani H. 1990. — Silurian and Devonian radiolarians from the Kurosegawa Tectonic Zone, southwest Japan. Journal of Earth Sciences Nagoya University 37: $157-192$.

WANG R. 1995. - Radiolarian fauna from Gufeng Formation (Lower Permian) in Hushan area of Nanjing, Jiangsu province. Scientia Geologica Sinica 30 (2): 139-148.

WANG Y. J. 2001. - A review of Paleozoic radiolarian research in China in the last century. Acta Micropaleontologica Sinica 18 (4): 313-320 (in Chinese with English abstract).

Webby B. D. \& Blom W. 1986. - The first well-preserved radiolarians from the Ordovician of Australia. Journal of Paleontology 60 (1): 145-157. https://doi.org/10.1017/S0022336000021594 
Won M. Z. 1997a. — Review of family Entactiniidae (Radiolaria), and taxonomy and morphology of Entactiniidae in the late Devonian (Frasnian) Gogo Formation, Australia. Micropaleontology 43 (4): 333-369. https://doi.org/10.2307/1485930

WON M. Z. 1997b. - The proposed new radiolarian subfamily Retentactiniinae (Entactiniidae) from the late Devonian (Frasnian) Gogo Formation, Australia. Micropaleontology 43 (4): 371-418. https://doi.org/10.2307/1485931

WON M. Z. \& BELOW R. 1999. - Cambrian radiolarians from the Georgina Basin, Queensland, Australia. Micropaleontology 45: 325-363. https://doi.org/10.2307/1486119

WON M.-Z. \& IAMS W. J. 2002. - Late Cambrian radiolarian faunas and biostratigraphy of the Cow Head Group, western Newfoundland. Journal of Paleontology 76: 1-33. https://doi. org/10.1017/S0022336000017315

Won M.-Z. \& IAMS W. J. 2011. — Earliest Arenig Radiolarians from the Cow Head Group, Western Newfoundland. Journal of Paleontology 85 (1): 156-177. https://doi.org/10.1666/10-102.1

Won M.-Z. \& IAMS W. J. 2015. - Review of the Beothuka terranova assemblage and characteristics of the middle Arenig (Ordovician, latest Floian) radiolarian assemblage from the Cow Head Group, Newfoundland. Neues Jahrbuch für Geologie und PaläontologieAbhandlungen 278: 1-21. https://doi.org/10.1127/njgpa/2015/0513 Won M.-Z., IAMS W. J. \& ReED K. 2005. — Earliest Ordovician (Early to Middle Tremadocian) radiolarian faunas of the Cow Head Group, Western Newfoundland. Journal of Paleontology 79: 433459. https://doi.org/10.1666/0022-3360(2005)079<0433:EOE $\mathrm{TMT}>2.0 . \mathrm{CO} ; 2$

Won M. Z., IAms W. J., Reed K. \& Below R. 2007. — Review of family Anakrusidae and its relationship to Kometia (Porifera: Hexactinellida). Journal of the Paleontological Society of Korea, 23: 73-91.

YAO A., MATSUDA T. \& IsOZAKI Y. 1980. — Triassic and Jurassic radiolarians from the Inuyama area, central Japan. Journal of Geosciences, Osaka City University 23 (4): 135-154.

Zhamoida A.-I. 1981. - Some results and problems of fossil radiolarian study, in Petrushevskaya M. G. \& Stepanjants S. D. (eds), Morphology, Ecology and Evolution of Radiolarians. Material from the IV symposium of European radiolarists EURORAD IV. Academy of Sciences of the U.S.S.R., Zoological Institute, 54-63. 